\title{
Article \\ Effects of Irrigation and Nitrogen Fertilization on Seed Yield, Yield Components, and Water Use Efficiency of Cleistogenes songorica
}

\author{
Qibo Tao ${ }^{1,2}$, Mengjie Bai ${ }^{1}\left(\right.$, Cunzhi Jia ${ }^{1}$, Yunhua Han ${ }^{1}$ and Yanrong Wang ${ }^{1, *}$ \\ 1 State Key Laboratory of Grassland Agro-Ecosystem, Key Laboratory of Grassland Livestock Industry \\ Innovation, Ministry of Agriculture and Rural Affairs, College of Pastoral Agriculture Science and \\ Technology, Lanzhou University, Lanzhou 730020, China; taoqb16@lzu.edu.cn (Q.T.); \\ baimj19@lzu.edu.cn (M.B.); jiaczh20@lzu.edu.cn (C.J.); hanyh@lzu.edu.cn (Y.H.) \\ 2 Grassland Agri-Husbandry Research Center, College of Grassland Science, Qingdao Agricultural University, \\ Qingdao 266109, China \\ * Correspondence: yrwang@lzu.edu.cn; Tel.: +86-0931-8910981
}

Citation: Tao, Q.; Bai, M.; Jia, C.;

Han, Y.; Wang, Y. Effects of Irrigation and Nitrogen Fertilization on Seed Yield, Yield Components, and Water Use Efficiency of Cleistogenes songorica. Agronomy 2021, 11, 466. https:// doi.org/10.3390/agronomy11030466

Academic Editor: Maik Veste

Received: 3 February 2021

Accepted: 28 February 2021

Published: 3 March 2021

Publisher's Note: MDPI stays neutral with regard to jurisdictional claims in published maps and institutional affiliations.

Copyright: $\odot 2021$ by the authors. Licensee MDPI, Basel, Switzerland. This article is an open access article distributed under the terms and conditions of the Creative Commons Attribution (CC BY) license (https:// creativecommons.org/licenses/by/ $4.0 /)$.
Abstract: Irrigation and nitrogen $(\mathrm{N})$ are two crucial factors affecting perennial grass seed production. To investigate the effects of irrigation and $\mathrm{N}$ rate on seed yield (SY), yield components, and water use efficiency (WUE) of Cleistogenes songorica (Roshevitz) Ohwi, an ecologically significant perennial grass, a four-year (2016-2019) field trial was conducted in an arid region of northwestern China. Two irrigation regimes (I1 treatment: irrigation at tillering stage; I2 treatment: irrigation at tillering, spikelet initiation, and early flowering stages) and four $\mathrm{N}$ rates $\left(0,60,120,180 \mathrm{~kg}^{-1}\right)$ were arranged. Increasing amounts of both irrigation and N improved SY, evapotranspiration, WUE, and related yield components like fertile tillers $\mathrm{m}^{-2}$ (FTSM) and seeds spikelet ${ }^{-1}$. Meanwhile, no significant difference was observed between 120 and $180 \mathrm{~kg} \mathrm{~N} \mathrm{ha}^{-1}$ treatments for most variables. The highest SY and WUE was obtained with treatment combination of I2 plus $120 \mathrm{~kg} \mathrm{~N}^{-1}$ with four-year average values of $507.3 \mathrm{~kg} \mathrm{ha}^{-1}$ and $1.8 \mathrm{~kg} \mathrm{ha}^{-1} \mathrm{~mm}^{-1}$, respectively. Path coefficient and contribution analysis indicated that FTSM was the most important yield component for SY, with direct path coefficient and contribution coefficient of 0.626 and 0.592 . Overall, we recommend I2 treatment (three irrigations) together with $120 \mathrm{~kg} \mathrm{~N} \mathrm{ha}^{-1}$ to both increase SY and WUE, especially in arid regions. Future agronomic managements and breeding programs for seed should mainly focus on FTSM. This study will enable grass seed producers, plant breeders, and government program directors to more effectively target higher SY of C. songorica.

Keywords: Cleistogenes songorica; irrigation; nitrogen application rate; path coefficient analysis; seed yield; seed yield components; water use efficiency

\section{Introduction}

Cleistogenes songorica (Roshevitz) Ohwi is a perennial Poaceae grass native to temperate arid, semi-arid, and desert areas of central Eurasia including northern China, Kazakhstan, Kyrgyzstan, Russia, Turkmenistan, Uzbekistan, and many other countries [1]. It is the dominant species in desert grasslands where annual precipitation is around $120 \mathrm{~mm}$, with significant ecological value (Figures S1 and S2) [2]. Because of a strong root system and excellent resistance to stress environments including drought, C. songorica has been considered as one of the most promising plant species for desert ecosystem and degraded grassland restoration [3,4]. Recently, a chromosome-level genome was sequenced to illustrate the mechanism underlying the drought tolerance of $C$. songorica [5]. Other than its ecological value, $C$. songorica also attracted more and more agronomic interest due to its good palatability and high nutritional value as forage, which plays a crucial role in developing local animal husbandry and grass-livestock systems [6].

Nevertheless, under native conditions, the seed yield (SY) of C. songorica is poor. The insufficient seed cannot meet the increasing demand from ecological restoration, grass- 
livestock programs, and many other sectors [7]. There is an urgent need to develop feasible methods to achieve a higher SY of $C$. songorica. The grass SY is a complicated quantitative character which is comprehensively affected by the environment, genetic background, and agronomic management [8,9]. As for perennial grass or forage legume-in contrast to grain crops-the progress of SY through plant breeding is scarce since current breeding programs mainly pay attention to vegetative biomass, stress resistance, and feeding quality [10]. As a result, the most practicable method to optimizing SY is to choose an appropriate seed production region and optimize the field agronomic managements used [11].

Water availability and nitrogen $(\mathrm{N})$ nutrient are two principal factors influencing growth and development of perennial grass, which are pivotal in deciding ultimate SY [12]. For perennial grass, water-deficit stress is well-known to cause serious yield loss [13], especially under arid and semi-arid environments [14], and irrigation is needed to avoid high SY penalty. On the other hand, it is noteworthy that perennial grass SY responses to water availability generally varied at different growth stages [12]. Previous research indicates that water deficiency during reproductive periods (such as heading and flowering stage) seems more detrimental for grass seed production because embryo abortion is caused by drought $[15,16]$. As a result, irrigation application at critical reproductive growth stages may a rational strategy for both SY and water use efficiency (WUE). Huettig et al. [17] found that a single irrigation applied at flowering lead to an average $31 \%$ increase for SY and 5\% increase for WUE of six tall fescue [Schedonorus phoenix (Scop.) Holub] cultivars. We hypothesized that adding water during reproductive period of $C$. songorica may also be beneficial for improving both SY and WUE.

The $\mathrm{N}$ is another key factor affecting growth and seed production of perennial grass because it stimulates fertile tiller formation and seed development $[18,19]$. The significance of $\mathrm{N}$ fertilization for grass seed production has been well recorded: Han et al. [20] reported that 190 and $140 \mathrm{~kg} \mathrm{~N} \mathrm{ha}^{-1}$ are needed to maximize SY of turf-type and forage-type tall fescue under arid environment of northwestern China. In northeastern China's Songnen Grassland, at least of $120 \mathrm{~kg} \mathrm{~N} \mathrm{ha}^{-1}$ is required to improve SY of Chinese sheepgrass (Leymus chinensis Trin.) [21]. Perennial ryegrass (Lolium perenne L.) seed crops in Oregon of USA need $60 \mathrm{~kg} \mathrm{~N} \mathrm{ha}^{-1}$ for maximum SY and seed quality [22]. As for perennial native grass, the knowledge is relatively rare. Previously, only López-García et al. [23] reported the $\mathrm{N}$ management practices for plains bristlegrass [Setaria vulpiseta (Lam.) Roem. and Schult.] and streambed bristlegrass [Setaria leucopila (Scribn. and Merr.) K. Schum.] native to the southern Great Plain of North America, the highest SY was obtained with the N application of 75 to $140 \mathrm{~kg} \mathrm{ha}^{-1}$.

The SY of perennial grass is affected directly or indirectly by the contributions of several SY components, such as the number of fertile tiller, number of seed, and seed weight [24]. Each yield component usually has a different level of significance for SY [25]. In such situation, analysis of critical SY components and contributions of each component to SY would gain knowledge of the formation of SY, which would in turn provide insights into selection for higher SY [26]. Path coefficient analysis (PCA) is a powerful tool for determining the contribution of each yield component to SY because this approach separates direct and indirect effects and measures the relative significance of the causal factors involved [24]. The PCA would provide us with an understanding of the nature of the interrelationships among SY and yield components [25] and has been successfully applied in Chinese sheepgrass [21], perennial ryegrass [24], switchgrass (Panicum virgatum L.) [27], smooth bromegrass (Bromus inermis L.) [25], and many other perennial grasses [15,28,29].

Although research concerning the irrigation and $\mathrm{N}$ fertilization for seed crops has been implemented for many perennial grasses, to the best of our knowledge studies on these important factors and their interaction effects for SY and water use characteristics of native grass $C$. songorica remain nonexistent. Besides, the contributions of several yield components to SY are still not very clear. Thus, the objective of this four-year field experiment was to determine the irrigation, $\mathrm{N}$ fertilization, and interaction effects on seed 
production and water use traits of $C$. songorica. We also aimed to analyze and describe the yield components responsible for SY by calculating path and contribution coefficients.

\section{Materials and Methods}

\subsection{Study Site}

The field experiments were conducted during four consecutive years (2016-2019) at Minqin Experimental Station of Lanzhou University in Wuwei, Gansu Province, northwestern China $\left(38^{\circ} 44^{\prime} \mathrm{N}, 103^{\circ} 01^{\prime} \mathrm{E} ; 1307 \mathrm{~m}\right.$ above sea level). The study site is located in a typical arid environment with a frost-free period of approximately 160 days. The average annual temperature was $8.8^{\circ} \mathrm{C}$ and annual mean precipitation was $120 \mathrm{~mm}$, with $90 \%$ of the total precipitation occurring during C. songorica growing season (April to September). The soil of the study site is a sandy loam with an average dry bulk density of $1.39 \mathrm{~g} \mathrm{~cm}^{-3}$. Before planting, the upper $30 \mathrm{~cm}$ soil had a $\mathrm{pH}$ of 7.68 , contained total $\mathrm{N}$ of $6.89 \mathrm{~g} \mathrm{~kg}^{-1}$, organic matter of $12.16 \mathrm{~g} \mathrm{~kg}^{-1}$, available $\mathrm{N}$ of $28.72 \mathrm{mg} \mathrm{kg}^{-1}$, available phosphorus of $17.53 \mathrm{mg} \mathrm{kg}^{-1}$, and available potassium of $113.95 \mathrm{mg} \mathrm{kg}^{-1}$. Before this experiment, silage maize (Zea mays L.) was grown at the site for three consecutive years. Monthly precipitation and monthly mean temperature during the growing seasons from 2016 to 2019 were reported in Figure 1.
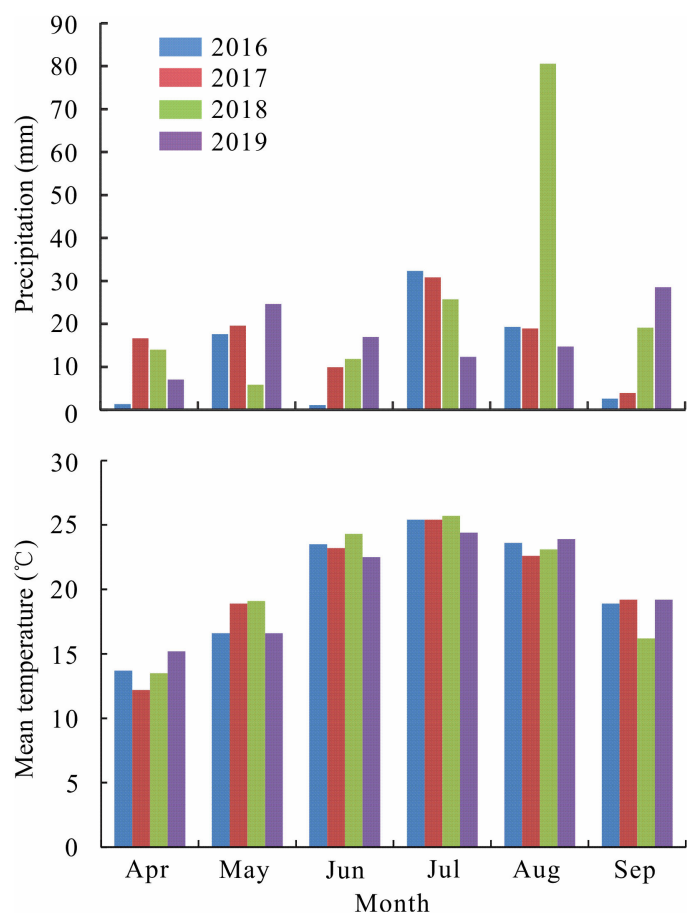

Figure 1. Monthly precipitation and mean temperature at Minqin Experimental Station of Lanzhou University during the growing seasons (April to September) from 2016 to 2019.

\subsection{Experimental Design and Plot Maintenance}

Treatments were arranged in a split-plot, randomized complete block design with three replications. The main plot treatments were irrigation with $50 \mathrm{~mm}$ at tillering stage (I1 treatment) and with $50 \mathrm{~mm}$ each at tillering, spikelet initiation, and early flowering stages (I2 treatment). A total of $50 \mathrm{~mm}$ and $150 \mathrm{~mm}$ water were added in I1 and I2 treatment yearly, respectively. In each irrigation event, water was added through a 63-mm plastic pipe, and a flow meter was used to measure the amount of water supplied. The subplot treatments were four $\mathrm{N}$ rates consisting of $0,60,120$, and $180 \mathrm{~kg} \mathrm{ha}^{-1}$ in each year, with half of the annual $\mathrm{N}$ applied in tillering stage, and the other half applied in spikelet initiation stage. The form of $\mathrm{N}$ was urea $\left[\mathrm{CO}\left(\mathrm{NH}_{2}\right)_{2}\right]$ and the fertilizer was broadcasted over soil and then raked lightly to incorporate with surface soil. The aims of one irrigation event in 
I1 treatment were to facilitate the $\mathrm{N}$ treatments because the precipitation during tillering (mid-May) was limited (Figure 1), and also ensure the grass survival under arid growth environment. Individual treatment plots were $4 \mathrm{~m}$ by $4 \mathrm{~m}$, with 3-m buffering zone between main plots, and 1-m spacing between adjacent plots in main plot. Weeds were removed by hand as needed during each growing season. No visible pests, pathogens, or plant disease were observed during experimental period, thus pesticide was not included in the present experiment.

In our research area, the re-growth of $C$. songorica was beginning in early April. Tillering, spikelet initiation, and early flowering stages occurred in mid-May, mid-July, and early August, respectively. The plots were harvested in late September when seeds matured from 2016 to 2019.

The grass was sown on 20-21 June 2014 by manually planting at $6.5 \mathrm{~kg} \mathrm{ha}^{-1}$ of seed with $30 \mathrm{~cm}$ row spacing. To ensure the successful establishment, diammonium phosphate $\left[\left(\mathrm{NH}_{4}\right)_{2} \mathrm{HPO}_{4}\right]$ and urea were applied before planting with 150 and $260 \mathrm{~kg} \mathrm{ha}^{-1}$, respectively. The $50 \mathrm{~mm}$ water was applied to all plots immediately after sowing and also on 1 July, 20 July, and 21 August 2014. The 50 mm water was applied on 11 November 2014 to guarantee winter survival.

\subsection{Data Collection}

The SY was determined from three, 1-m row segments taken from the center of each plot. Seed samples were dried, threshed, cleaned, weighted, and values converted to SY (kg $\mathrm{ha}^{-1}$ ) when the seed water content was $8 \%$ to $10 \%$. The yield components considered in this study included fertile tillers $\mathrm{m}^{-2}$ (FTSM), spikelets fertile tiller $^{-1}$ (SFT), seeds spikelet ${ }^{-1}$ (SS), and thousand seed weight (TSW). Three random 0.5-m row samples in each plot were sampled to measure the FTSM before seed harvest. Then, 50 undamaged fertile tillers and 50 spikelets in each plot were selected to determine the SFT and SS, respectively. Three 1000-seed samples from each plot were counted and weighted for the determination of TSW.

Before $C$. songorica re-growth and after harvesting in each growing season, soil water content (SWC) to a depth of $200 \mathrm{~cm}$ was measured for calculating soil water storage (SWS) in the soil profiles. One soil core (42 $\mathrm{mm}$ diameter) in each plot between two central rows were manually sampled at $20-\mathrm{cm}$ intervals, after their wet weight was weighted, the soil samples were dried at $105^{\circ} \mathrm{C}$ to a constant weight, the SWC was calculated on the basis of soil dry weight. The SWS was calculated according to the equation [30]:

$$
\text { SWS }=\sum h_{i} \times p_{i} \times b_{i} / 10
$$

where $h_{i}$ is the soil thickness $(\mathrm{cm}), p_{i}$ is the soil bulk density $\left(\mathrm{g} \mathrm{cm}^{-3}\right), b_{i}$ is SWC of each layer, and $i=20,40,60 \ldots, 200$. Evapotranspiration $(\mathrm{ET}, \mathrm{mm})$ was calculated using water balance formula [31]:

$$
E T=P+I+S W S_{0}-S W S_{1}
$$

where $P$ is precipitation during growing seasons $(\mathrm{mm}), I$ is irrigation amount $(\mathrm{mm}), S W S_{0}$ and $S W S_{1}$ are $S W S(\mathrm{~mm})$ before re-growth and after harvesting. WUE $\left(\mathrm{kg} \mathrm{ha}^{-1} \mathrm{~mm}^{-1}\right)$ was calculated using equation [32]:

$$
W U E=S Y / E T
$$

\subsection{Statistical Analysis}

All statistical analysis was performed using SPSS 19.0 software (SPSS Inc., Chicago, IL, USA). Data of SY and its components, ET, and WUE were subjected to analysis of variance (ANOVA). In the combined analysis, year, irrigation, and $\mathrm{N}$ treatment were treated as the fixed factors while block was considered as random factor. Significant differences between treatments were compared by Duncan's multiple comparisons test at $p<0.05$ level. All determinations reported were the means of three replications. The correlation and path 
coefficients were calculated to estimate the relative significance of each yield component to SY $(n=96)$, the contribution coefficient was defined to be the correlation coefficient of the SY and yield components multiplied by corresponding path coefficient, as described by Wang et al. [21].

\section{Results}

\subsection{Weather Conditions}

The monthly precipitation was quite variable during the four experimental years (Figure 1). The total precipitation in the growing seasons from 2016 to 2019 was 75.4, $100.9,158.1$, and $105.2 \mathrm{~mm}$, respectively. During anthesis and seed set period (August and September) there was obviously higher precipitation in $2018(100.0 \mathrm{~mm})$ than that in 2016 $(22.3 \mathrm{~mm}), 2017(23.2 \mathrm{~mm})$, and $2019(43.6 \mathrm{~mm})$. The monthly mean temperature showed less variation between four years and followed the typical pattern of temperate continental climate (Figure 1).

\subsection{Seed Yield}

The ANOVA indicated that SY was significantly influenced by all factors $(p<0.01)$ and by the irrigation $\times \mathrm{N}$ interaction $(p<0.05)$ (Table 1$)$.

Table 1. Analysis of variance for year, block, irrigation, nitrogen application, and their interaction effects on seed yield, yield components, evapotranspiration, and water use efficiency of Cleistogenes songorica.

\begin{tabular}{|c|c|c|c|c|c|c|c|c|}
\hline Items & Year (Y) & Block & Irrigation (I) & Nitrogen (N) & $\mathbf{Y} \times \mathbf{I}$ & $\mathbf{Y} \times \mathbf{N}$ & $\mathbf{I} \times \mathbf{N}$ & $\mathbf{Y} \times \mathbf{I} \times \mathbf{N}$ \\
\hline Degree of freedom & 3 & 2 & 1 & 3 & 3 & 9 & 3 & 9 \\
\hline Seed yield & $* * *$ & ns & $* *$ & $* * *$ & ns & ns & $*$ & ns \\
\hline Fertile tillers $\mathrm{m}^{-2}$ & $* * *$ & ns & $* *$ & $* * *$ & ns & $* * *$ & $* * *$ & $\mathrm{~ns}$ \\
\hline Spikelets fertile tiller ${ }^{-1}$ & $* * *$ & $\mathrm{~ns}$ & ns & $*$ & $\mathrm{~ns}$ & ns & ns & $\mathrm{ns}$ \\
\hline Seeds spikelet ${ }^{-1}$ & $* * *$ & ns & $* *$ & $* * *$ & $* * *$ & $* * *$ & * & $\mathrm{ns}$ \\
\hline Thousand seed weight & $* * *$ & ns & $*$ & $* * *$ & $* * *$ & ns & ns & ns \\
\hline Evapotranspiration & $* * *$ & ns & $* * *$ & $* * *$ & $* * *$ & ns & ns & ns \\
\hline Water use efficiency & $* * *$ & ns & $*$ & $* * *$ & ns & ns & ns & ns \\
\hline
\end{tabular}

Note: * Indicates significance at $p<0.05$ level; ${ }^{* *}$ Indicates significance at $p<0.01$ level; ${ }^{* * *}$ Indicates significance at $p<0.001$ level; ns, not significant at $p<0.05$ level.

The irrigation treatment affected SY sharply in both years. The SY with I2 treatment increased compared with I1 treatment by $41.2 \%$ in $2016,81.6 \%$ in $2017,38.6 \%$ in 2018 , and $158.8 \%$ in 2019 . In both years and irrigation treatments, the SY presented increasing responses with the increasing $\mathrm{N}$ doses up to $120 \mathrm{~kg} \mathrm{ha}^{-1}$ and then decreased or stabilized when $\mathrm{N}$ rate increased to $180 \mathrm{~kg} \mathrm{ha}^{-1}$. There was no significant difference for SY between 120 and $180 \mathrm{~kg} \mathrm{~N} \mathrm{ha}^{-1}$ (Figure 2).

Significant irrigation $\times \mathrm{N}$ effect was observed, the highest $\mathrm{SYs}$ were achieved with the treatment combination of $\mathrm{I} 2+120 \mathrm{~kg} \mathrm{~N} \mathrm{ha}^{-1}$ and I $2+180 \mathrm{~kg} \mathrm{~N}^{-1}$, with the average SY over four years of 507.3 and $520.4 \mathrm{~kg} \mathrm{ha}^{-1}$, respectively (Figure 2).

Except for treatments, yearly variation for SY was also evident, across all treatments, the average SY from 2016 to 2019 was 398.8, 342.2, 443.2, and $196.2 \mathrm{~kg} \mathrm{ha}^{-1}$, respectively (Figure 2).

In contrast to SY, seed quality was not significantly affected by irrigation and N fertilization treatments, similar final germination percentage (FGP), germination index, and mean germination time was observed for seeds harvested from different treatments. The FGP exceeded $90 \%$ in all treatments (data not shown). 

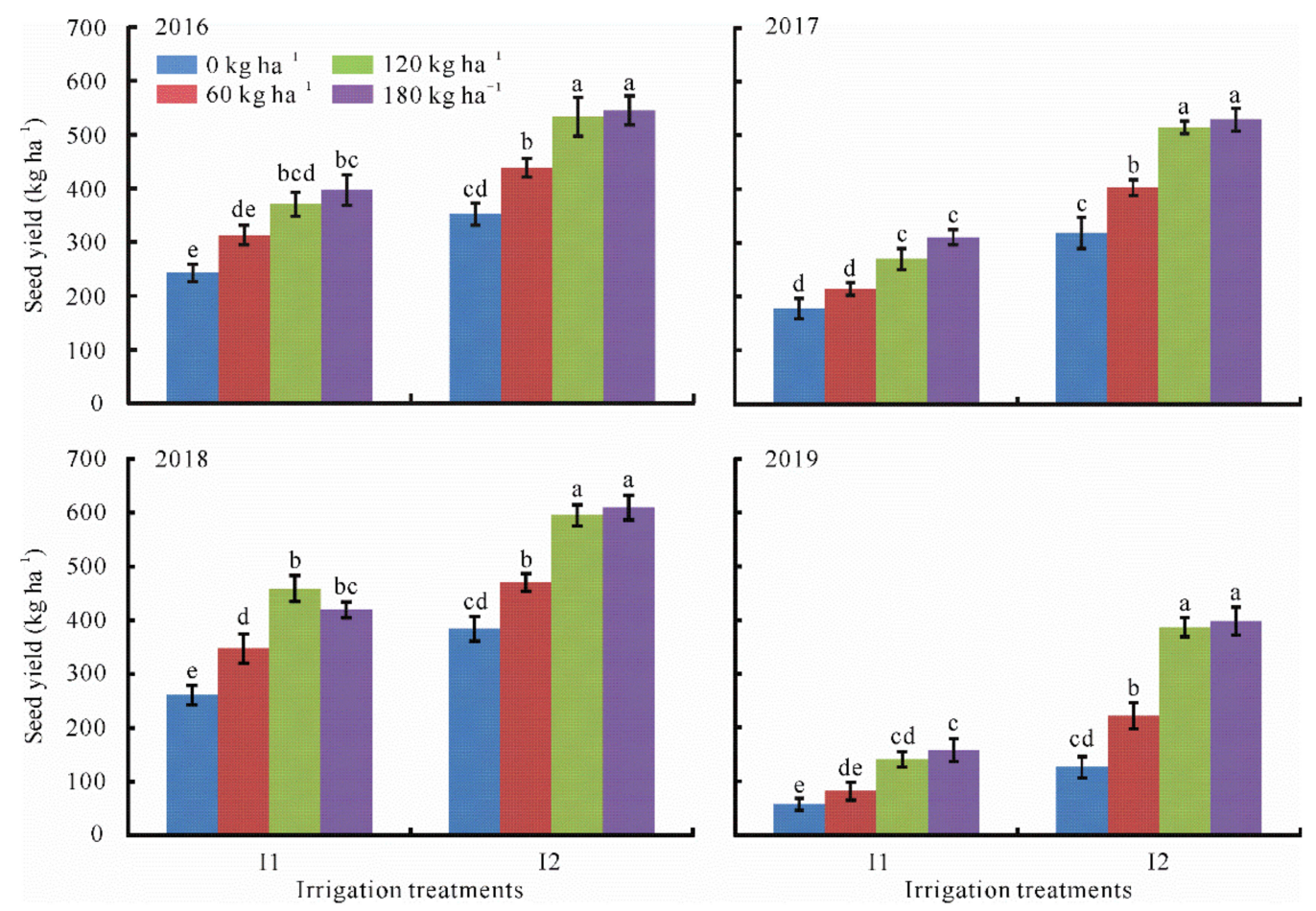

Figure 2. Effects of different irrigation and nitrogen rate treatments on Cleistogenes songorica seed yield from 2016 to 2019. Bars represent the standard errors $(n=3)$. Different lowercase letters above bars within a year indicate significant difference at $p<0.05$ level. I1: watering at tillering stage, a total of $50 \mathrm{~mm}$ water was added in each year; I2: watering at tillering, spikelet initiation, and early flowering stages, respectively, a total of $150 \mathrm{~mm}$ water was added in each year.

\subsection{Seed Yield Components}

All yield components were significantly affected by year, irrigation, and $\mathrm{N}$ treatment, except for irrigation effect which was not significant for SFT. The FTSM was significantly influenced by year $\times \mathrm{N}$ and irrigation $\times \mathrm{N}$ interaction. The SS was significantly influenced by year $\times$ irrigation, year $\times \mathrm{N}$, and irrigation $\times \mathrm{N}$ interaction. In addition, there was a significant effect of year $\times$ irrigation interaction for TSW. The three-way interaction had no impact on all tested yield components (Table 1).

Both yield components varied with irrigation and $\mathrm{N}$ treatments, except for SFT, which was relatively stable between treatments, there was only significantly difference between treatments I1 $+0 \mathrm{~kg} \mathrm{~N} \mathrm{ha}^{-1}$ and treatments I2 +60, 120, and $180 \mathrm{~kg} \mathrm{~N} \mathrm{ha}^{-1}$ in 2018 (Table 2). Compared with I1 treatment, the I2 treatment significantly improved FTSM and SS by $54.4 \%$ and $22.5 \%$ across four years and $\mathrm{N}$ rate treatments. Furthermore, when the means of FTSM and SS were compared between four $\mathrm{N}$ rates, we found that increasing $\mathrm{N}$ dose promoted positive effects, but no significant difference was recorded between 120 and $180 \mathrm{~kg} \mathrm{~N} \mathrm{ha}^{-1}$ treatments (except for SS in 2017, I1 treatment). Similar to SY, the highest values were observed in the treatment combinations of $\mathrm{I} 2+120$ or $180 \mathrm{~kg} \mathrm{~N}^{-1}$ (Table 2).

The TSW tended to increase with increasing irrigation and $\mathrm{N}$ dose, although the responses were neither consistent nor were they always statistically significantly. The I2 treatment increased the TSW by $0.001-0.006 \mathrm{~g}$ relative to I1 treatment, and fertilized plots showed 0.001-0.005 g greater TSW over zero N plots during four years (Table 2). 
Table 2. Effects of different irrigation and N rate treatments on Cleistogenes songorica seed yield components from 2016 to 2019 .

\begin{tabular}{|c|c|c|c|c|c|c|}
\hline Year & $\begin{array}{l}\text { Irrigation } \\
\text { Treatments }\end{array}$ & $\begin{array}{l}\text { N Rates } \\
\left(\mathrm{kg} \mathrm{ha}^{-1}\right)\end{array}$ & Fertile Tillers $\mathrm{m}^{-2}$ & $\begin{array}{c}\text { Spikelets } \\
\text { Fertile Tiller }^{-1}\end{array}$ & $\begin{array}{c}\text { Seeds } \\
\text { Spikelet }^{-1}\end{array}$ & $\begin{array}{c}\text { Thousand Seed } \\
\text { Weight (g) }\end{array}$ \\
\hline \multirow[t]{8}{*}{2016} & I1 & 0 & $633.1 \mathrm{e}$ & $9.01 \mathrm{a}$ & $26.1 \mathrm{f}$ & $0.225 b c$ \\
\hline & & 60 & $881.2 \mathrm{~d}$ & $8.91 a$ & $28.4 \mathrm{e}$ & $0.226 a b c$ \\
\hline & & 120 & $1266.2 b$ & $8.84 a$ & $31.5 c$ & $0.227 \mathrm{a}$ \\
\hline & & 180 & $1252.2 b$ & $8.81 a$ & $31.9 b c$ & $0.227 \mathrm{ab}$ \\
\hline & $\mathrm{I} 2$ & 0 & $985.5 c$ & $8.99 a$ & $29.7 d$ & $0.225 c$ \\
\hline & & 60 & $1354.9 b$ & $8.93 a$ & $33.0 \mathrm{~b}$ & $0.227 \mathrm{abc}$ \\
\hline & & 120 & $1800.6 \mathrm{a}$ & $8.87 a$ & $37.7 a$ & $0.228 \mathrm{a}$ \\
\hline & & 180 & $1863.6 \mathrm{a}$ & $8.83 a$ & $37.4 \mathrm{a}$ & $0.227 \mathrm{a}$ \\
\hline \multirow[t]{8}{*}{2017} & I1 & 0 & $627.7 \mathrm{e}$ & $8.71 a$ & $21.5 \mathrm{e}$ & $0.238 \mathrm{e}$ \\
\hline & & 60 & $910.0 \mathrm{~d}$ & $8.65 a$ & $25.5 d$ & $0.241 \mathrm{~cd}$ \\
\hline & & 120 & 1109.1c & $8.59 a$ & $30.1 c$ & $0.242 \mathrm{~cd}$ \\
\hline & & 180 & $1168.2 \mathrm{c}$ & $8.61 a$ & $32.8 b$ & $0.242 \mathrm{~cd}$ \\
\hline & $\mathrm{I} 2$ & 0 & $908.4 d$ & $8.66 a$ & $27.8 \mathrm{~d}$ & $0.241 \mathrm{~d}$ \\
\hline & & 60 & $1268.6 b$ & $8.57 a$ & $30.1 c$ & $0.243 b c$ \\
\hline & & 120 & $1662.9 a$ & $8.51 a$ & $37.3 a$ & $0.243 b$ \\
\hline & & 180 & $1700.2 a$ & $8.52 a$ & $37.3 a$ & $0.245 a$ \\
\hline \multirow[t]{8}{*}{2018} & $\mathrm{I} 1$ & 0 & $752.1 \mathrm{e}$ & $8.47 \mathrm{a}$ & $25.1 d$ & $0.237 \mathrm{~d}$ \\
\hline & & 60 & $1098.2 d$ & $8.35 \mathrm{ab}$ & $29.1 c$ & $0.241 \mathrm{abc}$ \\
\hline & & 120 & $1582.8 b c$ & $8.21 \mathrm{ab}$ & $35.1 b$ & $0.240 \mathrm{bc}$ \\
\hline & & 180 & $1666.8 b$ & $8.29 \mathrm{ab}$ & $34.8 \mathrm{~b}$ & $0.242 \mathrm{ab}$ \\
\hline & $\mathrm{I} 2$ & 0 & $1128.6 \mathrm{~d}$ & $8.32 \mathrm{ab}$ & $27.2 \mathrm{~cd}$ & $0.239 \mathrm{c}$ \\
\hline & & 60 & $1527.6 \mathrm{c}$ & $8.15 b$ & $33.1 b$ & $0.241 \mathrm{abc}$ \\
\hline & & 120 & $2211.2 \mathrm{a}$ & $8.10 \mathrm{~b}$ & $40.8 \mathrm{a}$ & $0.243 a$ \\
\hline & & 180 & $2149.8 \mathrm{a}$ & $8.11 b$ & $40.1 \mathrm{a}$ & $0.242 \mathrm{ab}$ \\
\hline \multirow[t]{8}{*}{2019} & I1 & 0 & $367.9 \mathrm{e}$ & $9.18 \mathrm{a}$ & $17.1 \mathrm{e}$ & $0.215 d$ \\
\hline & & 60 & $512.6 \mathrm{~d}$ & $9.15 a$ & $18.8 \mathrm{~d}$ & $0.216 \mathrm{~d}$ \\
\hline & & 120 & $655.6 c$ & $9.15 a$ & $24.4 c$ & $0.218 \mathrm{~cd}$ \\
\hline & & 180 & $745.9 c$ & $9.21 \mathrm{a}$ & $24.5 c$ & $0.218 \mathrm{~cd}$ \\
\hline & $\mathrm{I} 2$ & 0 & $650.2 c$ & $9.08 \mathrm{a}$ & $24.5 c$ & $0.220 \mathrm{bc}$ \\
\hline & & 60 & 861.0b & $9.07 a$ & $28.6 b$ & $0.222 \mathrm{ab}$ \\
\hline & & 120 & 1277.1a & $9.06 a$ & $33.2 \mathrm{a}$ & $0.224 a$ \\
\hline & & 180 & $1370.5 a$ & $9.01 a$ & $33.7 a$ & $0.224 a$ \\
\hline
\end{tabular}

Note: Different lowercase letters within a column and year indicate significant difference at $p<0.05$ level. I1: watering at tillering stage, a total of $50 \mathrm{~mm}$ water was added in each year; I2: watering at tillering, spikelet initiation, and early flowering stages, respectively, a total of $150 \mathrm{~mm}$ water was added in each year.

\subsection{Contributions of Seed Yield Components to Seed Yield}

All yield components are significantly correlated with SY $(p<0.001)$, the FTSM, SS, and TSW are positively correlated, while SFT is negatively correlated. The largest correlation coefficient was FTSM on SY (0.945) (Table 3).

Table 3. Correlation coefficients, path coefficients and contributions of yield components to the seed yield of Cleistogenes songorica $(n=96)$.

\begin{tabular}{|c|c|c|c|c|c|c|c|}
\hline \multirow{2}{*}{$\begin{array}{l}\text { Seed Yield } \\
\text { Components }\end{array}$} & \multirow{2}{*}{$\begin{array}{c}\text { Correlation } \\
\text { Coefficient with SY }\end{array}$} & \multirow{2}{*}{$\begin{array}{l}\text { Direct Path } \\
\text { Coefficients }\end{array}$} & \multicolumn{4}{|c|}{ Indirect Path Coefficients } & \multirow{2}{*}{$\begin{array}{c}\text { Contributions } \\
\text { to SY }\end{array}$} \\
\hline & & & FTSM & SFT & SS & TSW & \\
\hline FTSM & $0.945^{* * *}$ & 0.626 & & -0.020 & 0.286 & 0.053 & 0.592 \\
\hline SFT & $-0.577^{* * *}$ & 0.033 & -0.377 & & -0.149 & -0.084 & -0.019 \\
\hline SS & $0.926^{* * *}$ & 0.301 & 0.595 & -0.016 & & 0.047 & 0.279 \\
\hline TSW & $0.546^{* * *}$ & 0.099 & 0.333 & -0.028 & 0.142 & & 0.054 \\
\hline
\end{tabular}

Note: ${ }^{* * *}$ Indicates significance at $p<0.001$ level. FTSM: fertile tillers $\mathrm{m}^{-2}$; SFT: spikelets fertile tiller ${ }^{-1}$; SS: seeds spikelet ${ }^{-1}$; TSW: thousand seed weight; SY: seed yield. A yield component contribution to SY was defined as the correlation coefficient between the SY and the yield component multiplied by the corresponding direct path coefficient. 
The PCA indicated that FTSM had the strongest direct effect on SY with direct path coefficient of 0.626, followed by SS (0.301), TSW (0.099), and SFT (0.033). Additionally, the SS and TSW also indirectly influenced SY via FTSM, and the corresponding indirect path coefficient is 0.595 and 0.333 (Table 3).

Likewise, the analysis of contribution revealed that FTSM contributed to SY mostly, with the contribution coefficient of 0.592 (Table 3).

\subsection{Evapotranspiration and Water Use Efficiency}

The ET was significantly influenced by year, irrigation, and $\mathrm{N}$ rate treatment (Table 1), ranged from 225.6 to $302.0 \mathrm{~mm}, 193.1$ to $267.8 \mathrm{~mm}, 244.0$ to $307.9 \mathrm{~mm}$, and 137.6 to 264.3 $\mathrm{mm}$ in 2016, 2017, 2018, and 2019 growing seasons, respectively (Table 4). ET in I1 treatment was significantly lower than in I2 treatment during four years, but ET only significantly increased as N amount increased in 2016 and 2019. In 2017 and 2018, though an increased trend was observed with the increase of $\mathrm{N}$ amount, ET did not exhibit statistically significant difference between four $\mathrm{N}$ rate treatments (Table 4).

Table 4. Effects of different irrigation and $\mathrm{N}$ rate treatments on evapotranspiration and water use efficiency of Cleistogenes songorica seed crops from 2016 to 2019.

\begin{tabular}{|c|c|c|c|c|c|c|}
\hline Year & $\begin{array}{l}\text { Irrigation } \\
\text { Treatments }\end{array}$ & $\begin{array}{l}\text { N Rates } \\
\left(\mathrm{kg} \mathrm{ha}^{-1}\right)\end{array}$ & $\begin{array}{c}\text { Soil Water Storage } \\
\text { Before Re-Growth } \\
\text { (mm) }\end{array}$ & $\begin{array}{c}\text { Soil Water Storage } \\
\text { After Harvesting } \\
(\mathrm{mm})\end{array}$ & $\begin{array}{l}\text { Evapotranspiration } \\
\qquad(\mathrm{mm})\end{array}$ & 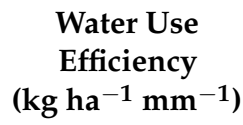 \\
\hline \multirow[t]{8}{*}{2016} & I1 & 0 & 435.9 & 335.7 & $225.6^{\mathrm{e}}$ & $1.1^{\mathrm{c}}$ \\
\hline & & 60 & 436.2 & 315.0 & $246.6^{d}$ & $1.3^{b c}$ \\
\hline & & 120 & 430.6 & 302.2 & $253.8^{\mathrm{cd}}$ & $1.5^{\mathrm{b}}$ \\
\hline & & 180 & 430.0 & 296.5 & $258.9^{\mathrm{c}}$ & $1.5^{\mathrm{ab}}$ \\
\hline & I2 & 0 & 437.2 & 386.2 & $276.5^{b}$ & $1.3^{b c}$ \\
\hline & & 60 & 435.4 & 373.8 & $287.0^{\mathrm{b}}$ & $1.5^{\mathrm{ab}}$ \\
\hline & & 120 & 437.3 & 363.8 & $298.8^{a}$ & $1.8^{\mathrm{a}}$ \\
\hline & & 180 & 434.3 & 357.7 & $302.0^{\mathrm{a}}$ & $1.8^{\mathrm{a}}$ \\
\hline \multirow[t]{8}{*}{2017} & I1 & 0 & 341.7 & 299.5 & $193.1^{b}$ & $0.9^{\mathrm{e}}$ \\
\hline & & 60 & 323.7 & 278.4 & $196.2^{b}$ & $1.1^{\mathrm{de}}$ \\
\hline & & 120 & 313.4 & 261.2 & $203.1^{b}$ & $1.3^{\mathrm{cd}}$ \\
\hline & & 180 & 312.6 & 255.3 & $208.2^{b}$ & $1.5^{b c}$ \\
\hline & I2 & 0 & 372.9 & 377.6 & $246.3^{a}$ & $1.3^{\mathrm{cd}}$ \\
\hline & & 60 & 366.5 & 365.1 & $252.3^{a}$ & $1.6^{\mathrm{b}}$ \\
\hline & & 120 & 354.3 & 341.1 & $264.1^{a}$ & $1.9^{\mathrm{a}}$ \\
\hline & & 180 & 350.9 & 334.0 & $267.8^{\mathrm{a}}$ & $2.0^{\mathrm{a}}$ \\
\hline \multirow[t]{8}{*}{2018} & I1 & 0 & 284.2 & 248.3 & $244.0^{\mathrm{b}}$ & $1.1^{\mathrm{e}}$ \\
\hline & & 60 & 286.7 & 247.3 & $247.5^{b}$ & $1.4^{\mathrm{cd}}$ \\
\hline & & 120 & 278.1 & 234.6 & $251.6^{b}$ & $1.8^{\mathrm{ab}}$ \\
\hline & & 180 & 274.5 & 224.4 & $258.1^{b}$ & $1.6^{b c}$ \\
\hline & $\mathrm{I} 2$ & 0 & 326.7 & 340.9 & $293.9^{a}$ & $1.3^{\mathrm{de}}$ \\
\hline & & 60 & 331.2 & 343.8 & $295.6^{a}$ & $1.6^{b c}$ \\
\hline & & 120 & 322.8 & 329.1 & $301.7^{a}$ & $2.0^{\mathrm{a}}$ \\
\hline & & 180 & 315.4 & 315.5 & $307.9^{\mathrm{a}}$ & $2.0^{\mathrm{a}}$ \\
\hline \multirow[t]{8}{*}{2019} & I1 & 0 & 245.4 & 263.0 & $137.6^{\mathrm{g}}$ & $0.4_{\mathrm{d}}$ \\
\hline & & 60 & 237.3 & 241.7 & $150.8^{f}$ & $0.5 \mathrm{~d}$ \\
\hline & & 120 & 228.8 & 217.1 & $166.8^{\mathrm{e}}$ & $0.8^{\mathrm{bc}}$ \\
\hline & & 180 & 223.9 & 201.7 & $177.4^{\mathrm{d}}$ & $0.9^{b}$ \\
\hline & I2 & 0 & 315.9 & 348.2 & $222.9^{c}$ & $0.6^{\mathrm{cd}}$ \\
\hline & & 60 & 323.5 & 338.8 & $240.0^{\mathrm{b}}$ & $0.9^{b}$ \\
\hline & & 120 & 313.8 & 320.2 & $248.9^{b}$ & $1.6^{\mathrm{a}}$ \\
\hline & & 180 & 303.4 & 294.3 & $264.3^{\mathrm{a}}$ & $1.5^{\mathrm{a}}$ \\
\hline
\end{tabular}

Note: Different lowercase letters within a column and year indicate significant difference at $p<0.05$ level. I1: watering at tillering stage, a total of $50 \mathrm{~mm}$ water was added in each year; I2: watering at tillering, spikelet initiation, and early flowering stages, respectively, a total of $150 \mathrm{~mm}$ water was added in each year. Evapotranspiration $=\mathrm{P}+\mathrm{I}+\mathrm{SWS}_{0}-\mathrm{SWS}_{1}$, where P is precipitation in growing seasons, I is total irrigation, $\mathrm{SWS}_{0}$ and $\mathrm{SWS}_{1}$ are soil water storage before re-growth and after harvesting. Precipitation in growing seasons from 2016 to 2019 was $75.4,100.9,158.1$, and $105.2 \mathrm{~mm}$, respectively. 
The WUE was consistently higher in I2 treatment than that in I1 treatment, with the former resulting in 19.7\%, 40.6\%, 15.6\%, and 68.9\% greater WUE than the latter from 2016 to 2019 , respectively. Among four N treatments, WUE was highest in 120 and $180 \mathrm{~kg} \mathrm{ha}^{-1}$ treatment and lowest in zero $\mathrm{N}$ treatment during four years. The treatment combination of I $2+120 \mathrm{~kg} \mathrm{~N} \mathrm{ha}^{-1}$ and I $+180 \mathrm{~kg} \mathrm{~N} \mathrm{ha}^{-1}$ consistently had the largest WUE with an average of $1.8 \mathrm{~kg} \mathrm{ha}^{-1} \mathrm{~mm}^{-1}$ over four years (Table 4 ).

Utilizing the observed results over four-year period, we explored the relationship between ET and SY (Figure 3). The relationship was described by a linear regression $\left(r^{2}=0.81 ; p<0.001\right)$, which indicated a linear increase of SY with a unit increase of ET. The relationship predicated an SY increase of $3.2 \mathrm{~kg} \mathrm{ha}^{-1}$ for each millimeter of ET above the threshold value $(137.6 \mathrm{~mm})$ required to produce the minimum SY.

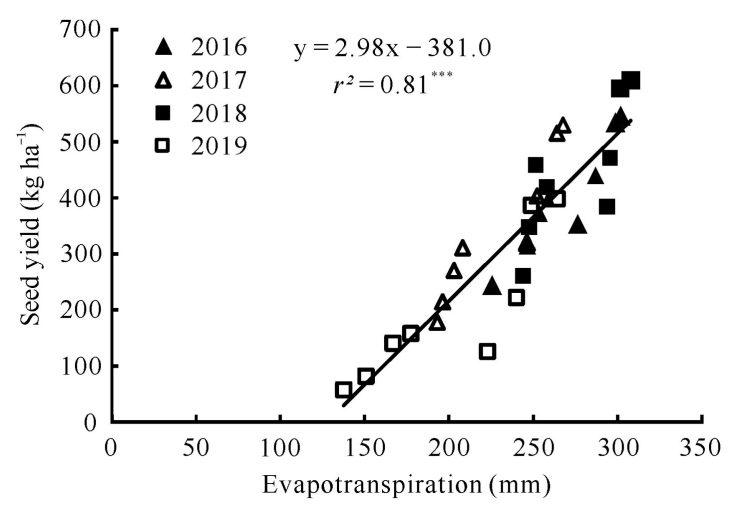

Figure 3. Relationship between evapotranspiration and seed yield of Cleistogenes songorica over four-year period. (Note: ${ }^{* *}$ Indicates significance at $p<0.001$ level).

\section{Discussion}

The perennial grass SY determines the economic viability of seed growers, and water availability is a key factor influencing SY, especially under arid and semi-arid environments [33]. It has been reported that grass seed crops are very sensitive to water-deficit stress during reproductive periods like anthesis and seed setting stages, thus strategic irrigation to support these critical stages is beneficial for improving SY [13]. In accordance with our hypothesis, the $C$. songorica SY was consistently improved by $\mathrm{I} 2$ treatment, despite the yearly precipitation in four growing seasons varying largely (Figure 2). Comparing with I1 treatment, two extra irrigation events during critical reproductive growth period were implemented in 12 treatment, which reduced the probability of water-deficit risk during flowering and subsequent seed filling stage, and ultimately resulted in much higher SY. This result parallels findings of Chastain et al. [34], who found the $16.6 \%$ increase of perennial ryegrass SY by a single irrigation at anthesis. However, our finding is in disagreement with a previous experiment conducted in Brazil reporting that irrigation had little influence on SY of signal grass (Urochloa decumbens Webster), under humid Brazil condition, water is not considered as a limiting factor [35].

$\mathrm{N}$ is an essential macro-element known to influence plant growth and seed development, for $\mathrm{N}$ positively participates in numerous plant metabolic processes including photosynthesis and acts as an important constituent of amino acids, chlorophyll, and nucleic acids, etc. [36]. Additionally, some researchers have suggested that $\mathrm{N}$ is involved in expression of some flowering genes, and on-off cycles in the gene expression levels was positively correlated with the $\mathrm{N}$ fertilization levels, thus in turn $\mathrm{N}$ fertilization can effectively increase SY [37]. Results from numerous field trials for perennial grass seed production showed that SY strongly responds to $\mathrm{N}$ fertilization; an appropriate $\mathrm{N}$ level generally has a positive impact on SY but after which yields are stagnant or reduced [20,23,35,38,39]. Similarly, current experiment showed that, under both irrigation conditions, the SY of C. songorica increased with increasing $\mathrm{N}$ level but did not differ significantly between 120 and $180 \mathrm{~kg} \mathrm{~N} \mathrm{ha}^{-1}$ treatment, which is consistent with earlier reports. Under our 
growing environment, the $\mathrm{N}$ application at a rate of $120 \mathrm{~kg} \mathrm{ha}^{-1}$ appeared adequate for optimizing C. songorica SY, previous reports indicated that recommended $\mathrm{N}$ rates for grass seed production was species specific, and also depended on cultivars, environments, and field management $[12,13,18,20,23,38-40]$.

Even though our trial was carried out with irrigation treatments, fluctuation of rainfall between years may play an important role in explaining yearly variation of SY. The obvious decrease of SY in 2019 may be mainly due to less precipitation in July and August. This result is in line with the findings of Wang et al. [15], who demonstrated that scanty precipitation during anthesis was detrimental for seed production of Russian wildrye (Psathyrostachys juncea Nevski). Moreover, the increased grass stand age may also be partly responsible for the conspicuous drop in C. songorica SY in 2019, as previously reported for Kentucky bluegrass (Poa pratensis L.) and intermediate wheatgrass [Thinopyrum intermedium (Host) Barkworth and D.R. Dewey] [40-42].

Among four tested yield components, the FTSM and SS were more responsive to irrigation and $\mathrm{N}$ fertilization treatments, while SFT and TSW were relatively constant. Typically, FTSM and SS were increased by I2 treatment and increasing N dose (Table 2). Gislum and Griffith [19] had concluded the fundamental function of $\mathrm{N}$ fertilization in development of perennial ryegrass fertile tiller. In the near research location with our study, accordant result was also reported by Han et al. [20] in which the fertile tillers number of tall fescues were increased with optimum $\mathrm{N}$ level. The better soil water availability in I2 treatment may also be beneficial for stimulating more vegetative tillers transfers to fertile tillers, and also ensure seed development to increase seed number. In addition, the water deficiency during flowering and beginning of seed fill may also cause fertile tiller death and seed abortion [13]. Similarly, a previous report in creeping red fescue (Festuca rubra L. var. rubra) indicated fertile tiller number was increased by extra irrigation and is in line with our results [12]. Besides, studies in tall fescue and perennial ryegrass had similar results, in which seed number was significantly improved by irrigation at anthesis [17,34].

The spikelet number and seed weight were generally considered as genetically manipulated traits and seldom influenced by agronomic treatments [43,44]. For example, Han et al. [20] found that $\mathrm{N}$ application had no impact on tall fescue SFT and was similar with our results in $\mathrm{C}$. songorica. The TSW increased somewhat by irrigation and $\mathrm{N}$ fertilization treatments (Table 2), and study in timothy grass (Phleum pratense L.) had consistent finding [45]. The improvement of seed weight may be mainly due to elevated assimilate uptake, storage, and transfer to seed [14], and also can be attributed to longer seed fill period resulting from supplemental irrigation at reproductive stages [34]. On the contrary, it is worth noting that changes of seed weight are often slight in the whole [46].

The results from PCA and contribution analysis revealed that FTSM had a considerable direct effect on SY, and also contributed most to SY, while other yield components were less important (Table 3). Fertile tiller is the basic biological unit in the formation of SY [25,47], and we found it changed with the yield change correspondingly, which accounted most for the variation of yield. Present research had similar results with those of several studies showing that fertile tiller number was the most significant yield component for SY in Russian wildrye [15], smooth bromegrass [43], creeping red fescue [48], and perennial ryegrass [49]. Nevertheless, our results differ from reports by Wang et al. [50], in which SFT was the most critical yield component for Siberian wildrye (Elymus sibiricus L.) SY. This might be because Siberian wildrye SFT was tremendously improved by phosphorus fertilization treatments and needs further research [50]. In the present experiment, SFT had negative indirect influences on SY via FTSM, SS, and TSW, which revealed the trade-off between these components.

In arid and semi-arid regions, water use traits are important for sustainable agricultural production [51]. ET is the total water consumption of agricultural system and is comprehensively affected by agronomic practices, weather conditions, and many factors; therefore, understanding the ET would help improve irrigation management and WUE [52]. Previous reports regarding ET of perennial grass seed crops were limited, but increasing 
the amount of water and $\mathrm{N}$ applied has been widely demonstrated to increase ET of crops including oilseed rape (Brassica napus L.), maize, and wheat (Triticum aestivum L.) [53-55]. This is because, under sufficient water and $\mathrm{N}$ applied situation, soil evaporation increased, meanwhile, larger leaf area and plant biomass resulted from high rate of water and $\mathrm{N}$ fertilization, which increased plant transpiration, thereby jointly increasing ET [52,55]. This was also confirmed here for $C$. songorica. In the present study, we found that $S Y$ is positively correlated with ET (Figure 3); studies for several crops also got similar results which is not unusual [56-58].

WUE of plants can be influenced by application of irrigation and $\mathrm{N}$ fertilization, we found that I2 $+120 \mathrm{~kg} \mathrm{~N} \mathrm{ha}^{-1}$ treatment consistently had the highest WUE in four years (Table 4). Our results differ somewhat from previous study for perennial ryegrass, in which single irrigation at anthesis reduced WUE. This may be due to the difference of effective rooting depth between different grasses, and also attributed to higher perennial ryegrass water use in irrigated plots $(363 \mathrm{~mm})$ [34]. However, our result is in agreement with the finding of Cookson et al. [59], who suggested that higher rate of $\mathrm{N}$ produces greater perennial ryegrass WUE than lower rates.

\section{Conclusions}

Based on findings of our four-year field trial, three irrigation events during growing season (tillering, spikelet initiation, and early flowering stage) together with an $\mathrm{N}$ rate of $120 \mathrm{~kg} \mathrm{ha}^{-1}$ resulted in increased C. songorica SY, WUE, and related yield components including FTSM and SS. Average SY and WUE over four years under this treatment was $507.3 \mathrm{~kg} \mathrm{ha}^{-1}$ and $1.8 \mathrm{~kg} \mathrm{ha}^{-1} \mathrm{~mm}^{-1}$, respectively. The SY was positively correlated with ET. With the highest direct path coefficient and contribution coefficient, the FTSM was the most pivotal yield component for SY. In conclusion, the irrigation at critical reproductive stages and optimum $\mathrm{N}$ application rate were the important aspects for successful seed production. We recommend the treatment combination of $\mathrm{I} 2+120 \mathrm{~kg} \mathrm{~N} \mathrm{ha}^{-1}$ for $C$. songorica seed production under arid environment of northwestern China, future agronomic managements and breeding objectives for seed should pay attention to FTSM to further increase SY.

Supplementary Materials: The following are available online at https://www.mdpi.com/2073-439 5/11/3/466/s1. Figure S1: A picture of Cleistogenes songorica plant. Figure S2: A picture of Cleistogenes songorica population in desert grassland.

Author Contributions: Conceptualization, Y.W., Y.H., and Q.T.; methodology, Q.T., C.J., and M.B.; validation, Y.W. and Q.T.; formal analysis, Q.T., M.B., and Y.H.; investigation, Q.T., Y.H., M.B., and C.J.; resources, Y.W. and Y.H.; data curation, Q.T., Y.H., and Y.W.; writing - original draft preparation, Q.T.; writing—review and editing, Y.W., Y.H., M.B., C.J., and Q.T.; supervision, Y.W., Y.H., and Q.T.; funding acquisition, Y.W. and Y.H. All authors have read and agreed to the published version of the manuscript.

Funding: This research was funded by the National Basic Research Program of China (No. 2014CB138704), National Natural Science Foundation of China (No. 31802129), China Agriculture Research System (No. CARS-34), and Program of Grassland Livestock Industry Research of Gansu Province (No. GCLM-2017-2).

Institutional Review Board Statement: Not applicable.

Informed Consent Statement: Not applicable.

Data Availability Statement: Not applicable.

Acknowledgments: The authors thank Xinyong Li for participating in the establishment of experimental field. We also appreciate Jiying Wang and Jinping Xue for lots of assistance in the field management and sample collection.

Conflicts of Interest: The authors declare no conflict of interest. 


\section{References}

1. Zhang, J.Y.; John, U.P.; Wang, Y.R.; Li, X.; Gunawardana, D.; Polotnianka, R.M.; Spangenberg, G.C.; Nan, Z.B. Targeted mining of drought stress-responsive genes from EST resources in Cleistogenes songorica. J. Plant Physiol. 2011, 168, 1844-1851. [CrossRef] [PubMed]

2. Yan, Q.; Wu, F.; Yan, Z.Z.; Li, J.; Ma, T.T.; Zhang, Y.F.; Zhao, Y.F.; Wang, Y.R.; Zhang, J.Y. Differential co-expression networks of long non-coding RNAs and mRNAs in Cleistogenes songorica under water stress and during recovery. BMC Plant Biol. 2019, 19, 23. [CrossRef]

3. Niu, X.L.; Nan, Z.B. Roots of Cleistogenes songorica improved soil aggregate cohesion and enhance soil water erosion resistance in rainfall simulation experiments. Water Air Soil Poll. 2017, 228, 109. [CrossRef]

4. Muvunyi, B.P.; Yan, Q.; Wu, F.; Min, X.Y.; Yan, Z.Z.; Kanzana, G.; Wang, Y.R.; Zhang, J.Y. Mining Late Embryogenesis Abundant (LEA) family genes in Cleistogenes songorica, a xerophyte perennial desert plant. Int. J. Mol. Sci. 2018, 19, 3430. [CrossRef] [PubMed]

5. Zhang, J.Y.; Wu, F.; Yan, Q.; John, U.K.; Cao, M.S.; Xu, P.; Zhang, Z.S.; Ma, T.T.; Zong, X.F.; Li, J.; et al. The genome of Cleistogenes songorica provides a blueprint for functional dissection of dimorphic flower differentiation and drought adaptability. Plant Biotechnol. J. 2020, 1-16. [CrossRef] [PubMed]

6. Tao, Q.B.; Lv, Y.Y.; Mo, Q.; Bai, M.J.; Han, Y.H.; Wang, Y.R. Impacts of priming on seed germination and seedling emergence of Cleistogenes songorica under drought stress. Seed Sci. Technol. 2018, 46, 239-258. [CrossRef]

7. Li, X.Y.; Wang, Y.R.; Wei, X.; Tai, J.H.; Jia, C.Z.; Hu, X.W.; Trethewey, J.A.K. Planting density and irrigation timing affects Cleistogenes songorica seed yield sustainability. Agron. J. 2014, 106, 1690-1696. [CrossRef]

8. Boe, A. Genetic and environmental effects on seed weight and seed yield in switchgrass. Crop Sci. 2003, 43, 63-67. [CrossRef]

9. Majidi, M.M.; Hoseini, B.; Abtahi, M.; Mirlohi, A.; Araghi, B. Genetic analysis of seed related traits in Orchardgrass (Dactylis glomerata) under normal and drought stress conditions. Euphytica 2015, 203, 409-420. [CrossRef]

10. Boelt, B.; Julier, B.; Karagić, Đ.; Hampton, J. Legume seed production meeting market requirements and economic impacts. Crit. Rev. Plant Sci. 2015, 34, 412-427. [CrossRef]

11. Hampton, J.G. Herbage seed lot vigor: Do problems start with seed production? J. Appl. Seed Prod. 1991, 9, 87-93.

12. Fairey, N.A. Effects of water and nitrogen on seed production of creeping red fescue. Can. J. Plant Sci. 2008, 88, 439-446. [CrossRef]

13. Hebblethwaite, P.D. Irrigation and nitrogen studies in s. 23 ryegrass grown for seed. 1. Growth, development, seed yield components and seed yield. J. Agric. Sci. 1977, 88, 605-614. [CrossRef]

14. Chen, Z.; Liu, X.; Niu, J.P.; Zhou, W.N.; Zhao, T.; Jiang, W.B.; Cui, J.; Kallenbach, R.; Wang, Q.Z. Optimizing irrigation and nitrogen fertilization for seed yield in western wheatgrass [Pascopyrum smithii (Rydb.) Á. Löve] using a large multi-factorial field design. PLoS ONE 2019, 14, e0218599. [CrossRef]

15. Wang, Q.Z.; Zhang, T.J.; Cui, J.; Wang, X.G.; Zhou, H.; Han, J.G.; Gislum, R. Path and ridge regression analysis of seed yield and seed yield components of Russian wildrye (Psathyrostachys juncea Nevski) under field conditions. PLoS ONE 2011, 6, e18245. [CrossRef] [PubMed]

16. Elgersma, A. Seed yield related to crop development and to yield components in nine cultivars of perennial ryegrass (Lolium perenne L.). Euphytica 1990, 49, 141-154. [CrossRef]

17. Huettig, K.D.; Chastain, T.G.; Garbacik, C.J.; Young, W.C.; Wysocki, D.J. Spring irrigation of tall fescue for seed production. Field Crop. Res. 2013, 144, 297-304. [CrossRef]

18. Young, W.C.; Chilcote, D.O.; Youngberg, H.W. Spring-applied nitrogen and productivity of cool-season grass seed crops. Agron. J. 1999, 91, 339-343. [CrossRef]

19. Gislum, R.; Griffith, S. Tiller production and development in perennial ryegrass in relation to nitrogen use. J. Plant Nutr. 2005, 27, 2135-2148. [CrossRef]

20. Han, Y.H.; Hu, T.M.; Wang, X.G.; Hannaway, D.B.; Li, J.; Mao, P.S.; Cui, Z.M.; Zhu, Z.L.; Wang, Z.W. Effects of seeding rate and nitrogen application on tall fescue seed production. Agron. J. 2014, 106, 119-124. [CrossRef]

21. Wang, J.F.; Xie, J.F.; Zhang, Y.T.; Gao, S.; Zhang, J.T.; Mu, C.S. Methods to improve seed yield of Leymus chinensis based on nitrogen application and precipitation analysis. Agron. J. 2010, 102, 227-281. [CrossRef]

22. Young, W.C.; Youngberg, H.W.; Chilcote, D.O. Spring nitrogen rate and timing influence on seed yield components of perennial ryegrass. Agron. J. 1996, 88, 947-951. [CrossRef]

23. López-García, J.A.; Ocumpaugh, W.R.; Ortega-Santos, J.A.; Reilley-Lloyd, J.; Muir, J.P. North American bristlegrass seed yield response to nitrogen fertilizer and environment. Crop Sci. 2011, 51, 361-369. [CrossRef]

24. Abel, S.; Gislum, R.; Boelt, B. Path and correlation analysis of perennial ryegrass (Lolium perenne L.) seed yield components. J. Agron. Crop Sci. 2017, 203, 338-344. [CrossRef]

25. Wang, Q.Z.; Cui, J.; Wang, X.G.; Zhang, T.J.; Zhou, H.; Hu, T.M.; Han, J.G. Algorithmic models of seed yield and its components in smooth bromegrass (Bromus inermis L.) via large sample size under field conditions. Euphytica 2012, 185, 363-375. [CrossRef]

26. Fırıncıoğlu, H.K.; Ünal, S.; Erbektaş, E.; Dogruyol, L. Relationships between seed yield and yield components in common vetch (Vicia sativa ssp. sativa) populations sown in spring and autumn in central Turkey. Field Crop. Res. 2010, 116, 30-37. [CrossRef]

27. Das, M.K.; Taliaferro, C.M. Genetic variability and interrelationships of seed yield and yield components in switchgrass. Euphytica 2009, 167, 95-105. [CrossRef]

28. Sukhchain; Sidhu, B.S. Correlation and path coefficients analysis for reproductive traits in Guinea grass. Euphytica 1992, 60, 57-60. 
29. Fang, C.; Aamlid, T.S.; Jørgensen, Ø.; Rognli, A. Phenotypic and genotypic variation in seed production traits within a full-sib family of meadow fescue. Plant Breed. 2004, 123, 241-246. [CrossRef]

30. Jia, Q.M.; Sun, L.F.; Ali, S.; Zhang, Y.; Liu, D.H.; Kamran, M.; Zhang, P.; Jia, Z.K.; Ren, X.L. Effect of planting density and pattern on maize yield and rainwater use efficiency in the Loess Plateau in China. Agric. Water Manag. 2018, 202, 19-32. [CrossRef]

31. Gu, X.B.; Cai, H.J.; Zhang, Z.T.; Fang, H.; Chen, P.P.; Huang, P.; Li, Y.P.; Li, Y.N.; Zhang, L.; Zhou, J.M.; et al. Ridge-furrow full film mulching: An adaptive management strategy to reduce irrigation of dryland winter rapeseed (Brassica napus L.) in northwest China. Agric. Forest Meteorol. 2019, 266-277, 119-128. [CrossRef]

32. Rana, G.; Katerji, N. Measurement and estimation of actual evapotranspiration in the field under Mediterranean climate: A review. Eur. J. Agron. 2000, 13, 125-153. [CrossRef]

33. Guo, Z.G.; Liu, H.X.; Wang, Y.R.; Hu, Y.K.; Yang, J.N. Irrigation at podding and regrowth stages increases seed yield and improves pod distribution in lucerne grown in the Hexi Corridor in China. New Zeal. J. Agric. Res. 2007, 50, $285-290$.

34. Chastain, T.G.; King, C.M.; Garbacik, C.J.; Young, W.C.; Wysocki, D.J. Irrigation frequency and seasonal timing effects on perennial ryegrass (Lolium perenne L.) seed production. Field Crop. Res. 2015, 180, 126-134. [CrossRef]

35. Canto, M.W.; Júnior, E.J.P.; Neto, A.B.; Bremm, C.; Vier, P.U.; Costa, A.C.S. Effects of nitrogen fertilization and irrigation on seed yield and yield components of signal grass (Urochloa decumbens). Crop Pasture Sci. 2020, 71, 294-303. [CrossRef]

36. Wang, M.Y.; Hou, L.Y.; Zhu, Y.Q.; Zhang, Q.; Wang, H.; Xia, F.S.; Chen, L.L.; Mao, P.S.; Hannaway, D.B. Siberian wildrye seed yield limited by assimilate source. Field Crop. Res. 2018, 218, 18-23. [CrossRef]

37. Miyazaki, Y.; Maruyama, Y.; Chiba, Y.; Kobayashi, M.J.; Joseph, B.; Shimizu, K.K.; Mochida, K.; Hiura, T.; Kon, H.; Satake, A. Nitrogen as a key regulator of flowering in Fagus crenata: Understanding the physiological mechanism of masting by gene expression analysis. Ecol. Lett. 2014, 17, 1299. [CrossRef] [PubMed]

38. Chen, J.S.; Zhu, R.F.; Zhang, Y.X. The effect of nitrogen addition on seed yield and yield components of Leymus chinensis in Songnen Plain, China. J. Soil Sci. Plant Nut. 2013, 13, 329-339. [CrossRef]

39. Huang, L.H.; Liang, Z.W.; Suarez, D.L.; Wang, Z.C.; Wang, M.M. Effects of continuous nitrogen application on seed yield, yield components and nitrogen-use efficiency of Leymus chinensis in two different saline-sodic soils of Northeast China. Crop Pasture Sci. 2019, 70, 373-383. [CrossRef]

40. Evans, D.W.; Canode, C.L. Influence of nitrogen fertilization, gapping, and burning on seed production of Newport Kentucky bluegrass. Agron. J. 1971, 63, 575-580. [CrossRef]

41. Jungers, J.M.; DeHaan, L.R.; Betts, K.J.; Sheaffer, C.C.; Wyse, D.L. Intermediate wheatgrass grain and forage yield responses to nitrogen fertilization. Agron. J. 2017, 109, 462-472. [CrossRef]

42. Hunter, M.C.; Sheaffer, C.C.; Culman, S.W.; Jungers, J.M. Effects of defoliation and row spacing on intermediate wheatgrass I: Grain production. Agron. J. 2020, 112, 1748-1763. [CrossRef]

43. Han, Y.H.; Wang, X.G.; Hu, T.M.; Hannaway, D.B.; Mao, P.S.; Zhu, Z.L.; Wang, Z.W.; Li, Y.X. Effect of row spacing on seed yield and yield components of five cool-season grasses. Crop Sci. 2013, 53, 2623-2630. [CrossRef]

44. Loeppky, H.A.; Horton, P.R.; Bittman, S.; Townley-Smith, L.; Wright, T.; Nuttall, W.F. Forage seed yield response to N and P fertilizers and soil nutrients in northeastern Saskatchewan. Can. J. Soil Sci. 1999, 79, 265-271. [CrossRef]

45. Lambert, D.A. The effects of nitrogen and irrigation on timothy (Phleum pratense) grown for seed production of seed. II. Reproductive growth and yield of seed. J. Agric. Sci. 1967, 69, 231-239. [CrossRef]

46. Young, W.C.; Youngberg, H.W.; Silberstein, T.B. Management studies on seed production of turf-type tall fescue. II. Seed yield components. Agron. J. 1998, 90, 478-483. [CrossRef]

47. Murphy, J.S.; Briske, D.D. Regulation of tillering by apical dominance: Chronology, interpretive value, and current perspective. J. Range Manag. 1992, 45, 419-429. [CrossRef]

48. Meints, P.D.; Chastain, T.G.; Young, W.C.; Banowetz, G.M.; Garbacik, C.J. Stubble management effects on three creeping red fescue cultivars grown for seed production. Agron. J. 2001, 93, 1276-1281. [CrossRef]

49. Deleuran, L.C.; Boelt, B. Establishment techniques in under-sown perennial ryegrass for seed production. Acta Agric. Scand. Sect. B Plant Soil Sci. 2009, 59, 57-62. [CrossRef]

50. Wang, M.Y.; Hou, L.Y.; Zhang, Q.; Yu, X.N.; Zhao, L.; Lu, J.X.; Mao, P.S.; Hannaway, D.B. Influence of row spacing and P and N applications on seed yield components and seed yield of Siberian wildrye (Elymus sibiricus L.). Crop Sci. 2017, 57, $2205-2212$. [CrossRef]

51. Ran, H.; Kang, S.Z.; Li, F.S.; Du, T.S.; Ding, R.S.; Li, S.E.; Tong, L. Responses of water productivity to irrigation and N supply for hybrid maize seed production in an arid region of Northwest China. J. Arid Land 2017, 9, 504-514. [CrossRef]

52. Gu, X.B.; Li, Y.N.; Du, Y.D. Effects of ridge-furrow film mulching and nitrogen fertilization on growth, seed yield and water productivity of winter oilseed rape (Brassica napus L.) in Northwestern China. Agric. Water Manag. 2018, 200, 60-70. [CrossRef]

53. Li, H.; Cong, R.H.; Ren, T.; Li, X.K.; Ma, C.B.; Zheng, L.; Zhang, Z.; Lu, J.W. Yield response to N fertilizer and optimum N rate of winter oilseed rape under different soil indigenous N supplies. Field Crop. Res. 2015, 181, 52-59. [CrossRef]

54. Jia, Q.M.; Sun, L.F.; Wang, J.J.; Li, J.; Ali, S.; Liu, T.N.; Zhang, P.; Lian, Y.H.; Ding, R.X.; Ren, X.L.; et al. Limited irrigation and planting densities for enhanced water productivity and economic returns under the ridge-furrow system in semi-arid regions of China. Field Crop. Res. 2018, 221, 207-218. [CrossRef]

55. Wang, D.; Yu, Z.W.; White, P.J. The effect of supplemental irrigation after jointing on leaf senescence and grain filling in wheat. Field Crop. Res. 2013, 151, 35-44. [CrossRef] 
56. Hergert, G.W.; Margheim, J.F.; Pavlista, A.D.; Martin, D.L.; Isbell, T.A.; Supalla, R.J. Irrigation response and water productivity of deficit to fully irrigated spring camelina. Agric. Water Manag. 2016, 177, 46-53. [CrossRef]

57. Hergert, G.W.; Margheim, J.F.; Pavlista, A.D.; Martin, D.L.; Supalla, R.J.; Isbell, T.A. Yield, irrigation response, and water productivity of deficit to fully irrigated spring canola. Agric. Water Manag. 2016, 168, 96-103. [CrossRef]

58. Zhang, H.; Wang, X.; You, M.; Liu, C. Water-yield relations and water-use efficiency of winter wheat in the North China Plain. Irrigation Sci. 1999, 19, 37-45. [CrossRef]

59. Cookson, W.R.; Rowarth, J.S.; Cameron, K.C. Effects of nitrogen fertilizer on the irrigation requirements of a perennial ryegrass (Lolium perenne L.) seed crop. J. Appl. Seed Prod. 1997, 15, 95-98. 